\title{
Impact of Rupee Exchange Rate on Business Opportunities in India
}

\author{
Nirav Desai, Sudha Rani Edupuganti, Shwetha Bhat, Kritika Bansal, \\ Prof. Harshali \\ Symbiosis Institute of Computer Studies and Research
}

\begin{abstract}
In this paper, we present an analysis of the macro economy in India with respect to the exchange rate of the Rupee and de regulation of oil prices. These 2 factors have been critical in deciding the business competitiveness of the economy and their individual effects are studied. Various business competencies arising from strong and weak Rupee as well as de-regulated prices of oil are discussed.
\end{abstract}

Key Words: exchange rate, de-regulation, devaluation, export competitiveness, trade deficit, fuel subsidy, macroeconomics, union budget

\section{Introduction}

In this paper, we present an analysis of the macro economy in India with respect to the exchange rate of the Rupee and de regulation of oil prices. These 2 factors have been critical in deciding the business competitiveness of the economy and their individual effects are studied. Various business competencies arising from strong and weak Rupee as well as de-regulated prices of oil are discussed.

\section{History}

When India became independent in 1947, the Rupee was equivalent to 1 US Dollar[1]. India was a closed economy at that time and the government followed a policy of License Raj[2] where in government permissions were needed for almost all aspects of doing business. This led to a severe credit crunch in the economy and the Government had to sell its gold bullion to raise capital reserves in 1991[3].

Dr. Manmohan Singh, the then Finance Minister of India under Prime Minister Narasimha Rao, embarked on a process of liberalizationin 1991, where in the economy was gradually opened up to private businesses, import and export. As a part of the liberalization policy, Dr. Manmohan Singh [4] did a partial float of the Rupee and the exchange rate dropped to Rs.30 to a US Dollar immediately after. The weaker Rupee boosted the exports and India saw its first trade surplus in the years 2000-01 [5]. A surplus has not been recorded in India since.

The opening up of the economy to trade and private businesses led to the rapid development of the services industry in India such as call centres and BPOs. Value added IT services also developed eventually and led to the growth of IT companies such as Infosys and Wipro. As the Rupee devalued against the Dollar year over year, the margins of export led companies kept improving [6].

Present scenario:The export competitiveness arising from the weak Rupee came at a cost. In order to keep inflation low in a country which imports $16 \%$ of its coal and $85 \%$ of its oil [7], the government subsidized the oil marketing companies to ensure the price of petrol and diesel at the pump did not go up. As the Rupee devalued, this part of the Government subsidy kept increasing. In 2008-09 the Government subsidy on petrol, diesel, kerosene and LPG reached Rs. 100,000 crore [Figure 2]. This was close to half the Government budget. Consequently oil prices in India were de-regulated in 2010 [8]. The Government put forward a road map to complete de-regulation of price of diesel and petrol and in October 2014 diesel price was completely deregulated [9]. 
Impact of de-regulation of oil price on the Indian Economy:

\section{Exchange Rate vs Price of Imported Oil: Direct Correlation here}

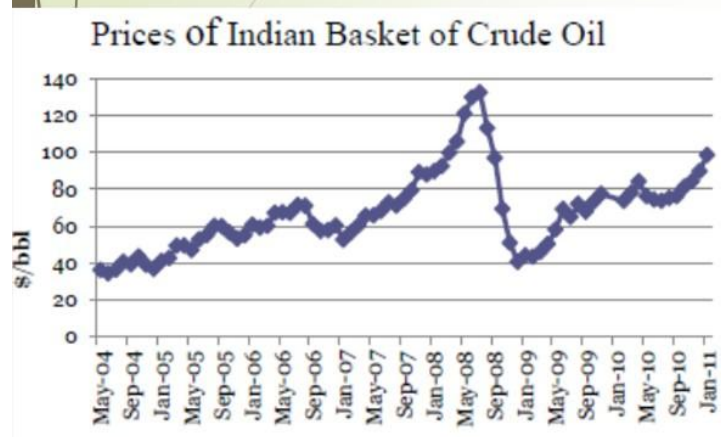

Source: Indian Oil Corporation Ltd.

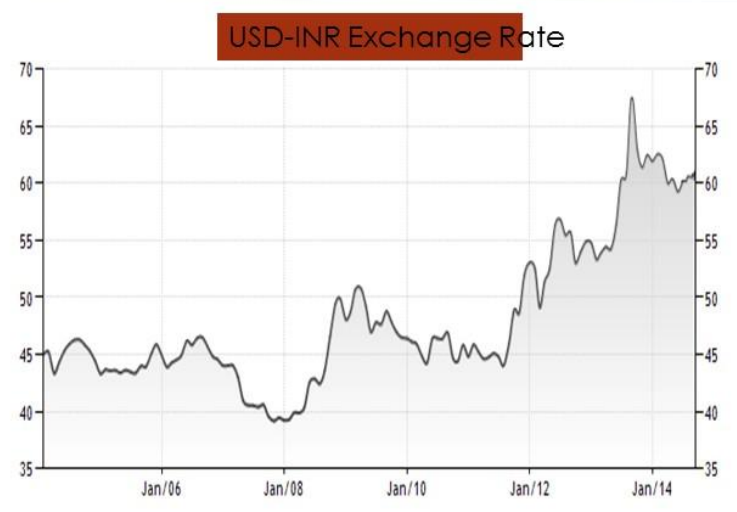

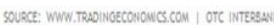

Figure 1: Impact of exchange rate on the price of oil

The de-regulation of oil price in India had a very significant impact on the economy. The chart above shows the price of the Indian basket of crude oil as stated by Indian Oil Corporation. On the right is the chart of the Rupee exchange rate. The important point to observe over here is that the oil is priced in US Dollars and so the price of oil increases if the Rupee depreciates (even though the demand may go up). This anomaly in the fundamental law of economics on demand and supply has bankrupted the Government of India. In the year 2014, the Government will be spending Rs. 63,430 crores on fuel subsidies [10].

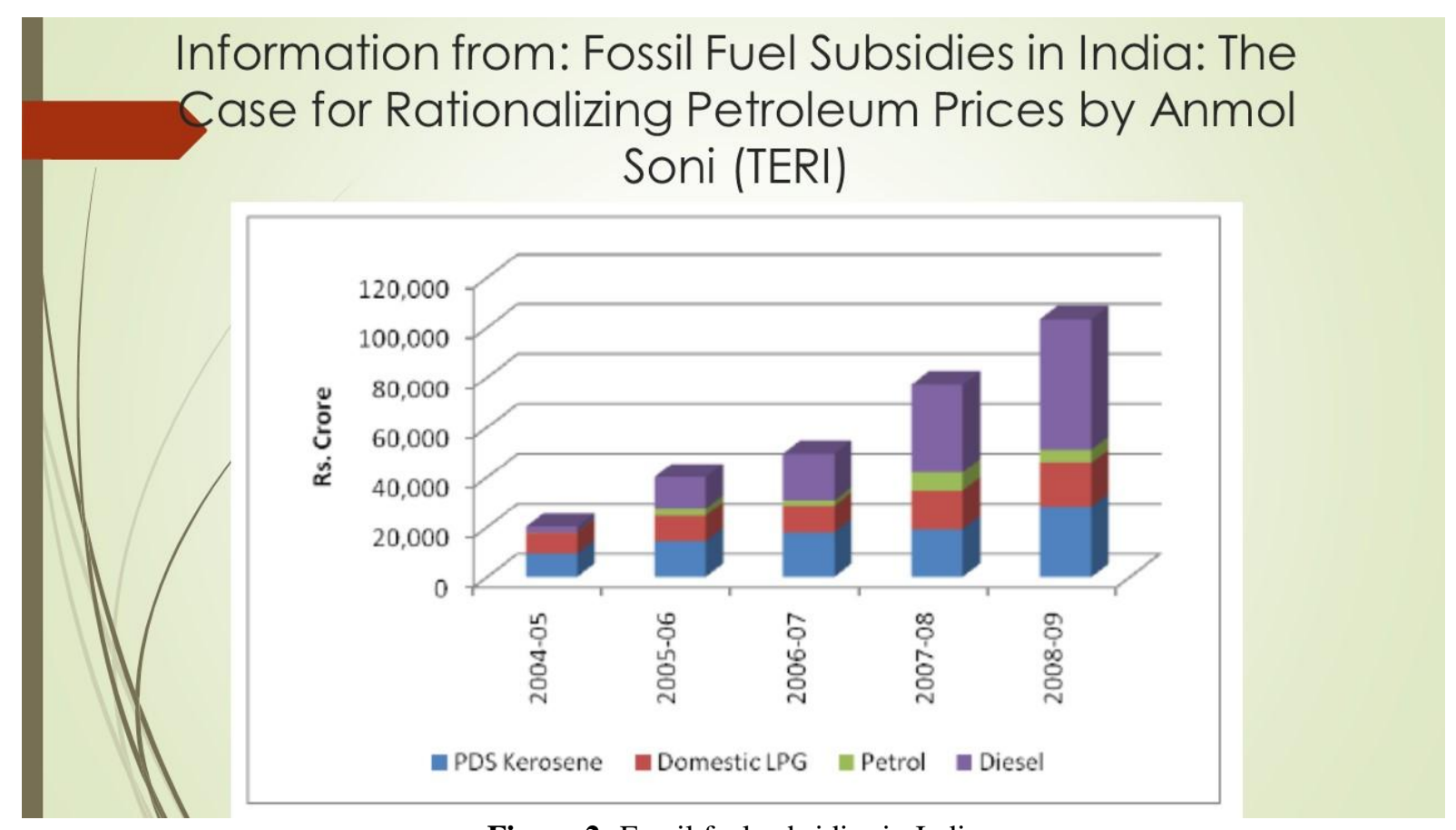

Figure 2: Fossil fuel subsidies in India 
Scenario post de-regulation: As per the present road map of the Government, petrol price is on its way to complete de-regulation and diesel price has already been fully de-regulated. This has completely changed the dynamics of the macro economy. Every time the Rupee depreciates, price of oil rises and increases the inflation in this country. This is evident from the figure below:

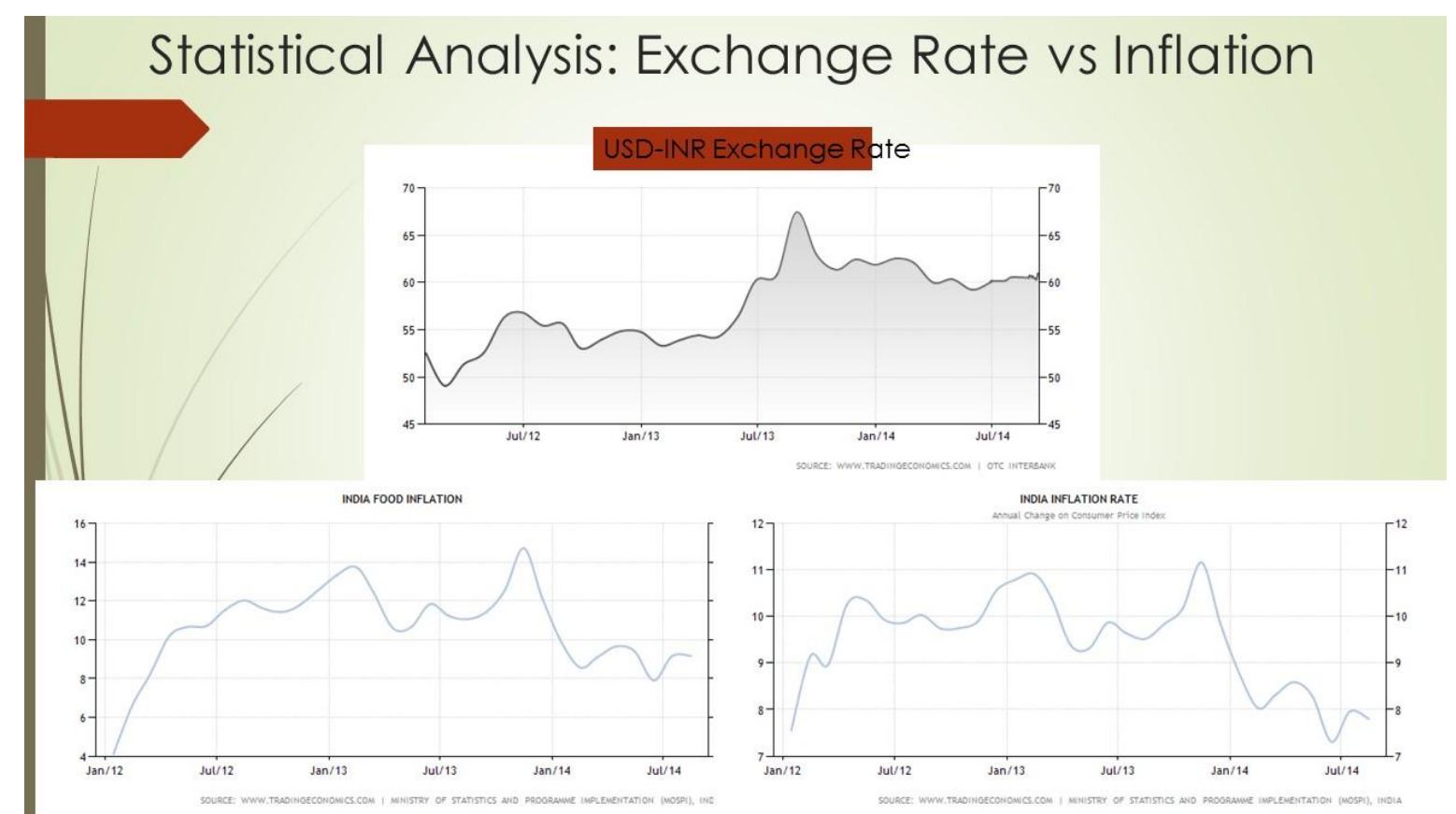

Figure 3: Charts showing the Rupee exchange rate vs US Dollar (top), food inflation (bottom left) and consumer price inflation (bottom right). All data from tradingeconomics.com

High inflation is not good for consumers and producers alike. For consumers this means higher cost of food (fruits, vegetables and food grains) and also higher cost of fuel. In fact, a small rise in the price of petrol or diesel can have a multiplier effect in the supply chain as at each stage the price will go up to maintain the margins of the business person. For producers, this will reflect in higher input costs and the only options they will have is to operate on a lower margin with reduced profits or increase the prices with reduced sales. This is evident in the figure below:

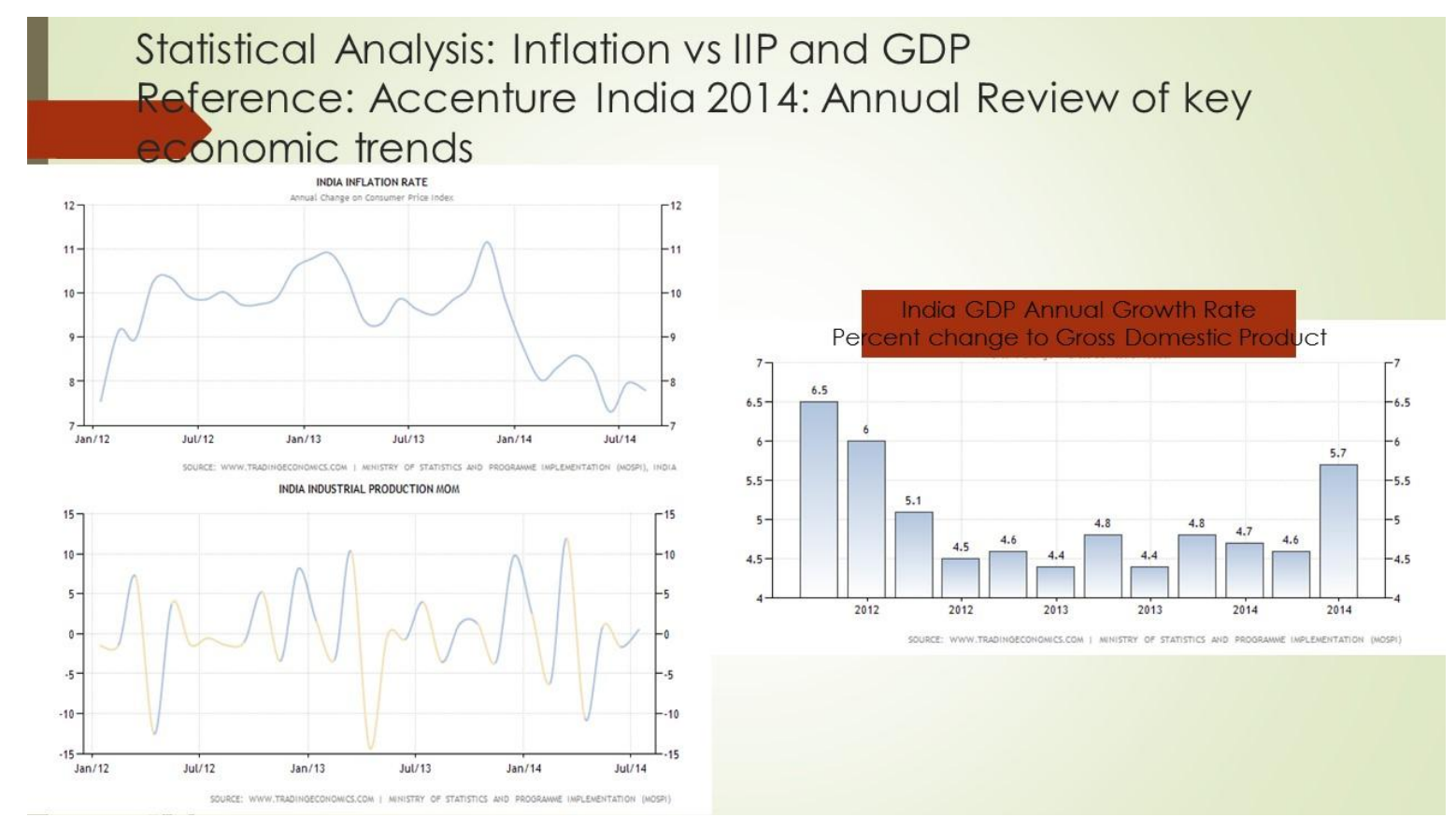

Figure 4: High inflation leads to a reduced IIP (Index of Industrial Production) as the purchasing managers decided to postpone any new purchases and production cycles till the inflation eases and the costs are lower. As 
can be seen, the IIP (bottom left) becomes negative every time the inflation spikes (top left). The GDP is net

lower due to this effect as can be seen in the figure on the right. All data from tradingeconomics.com

If the oil and subsidies are removed, the Government stands to gain Rs.63,600 crore per year at the present exchange rate of Rs.60 to a US Dollar. This capital freed up by the Government could be used on infrastructure and IT projects along with other social welfare schemes. This would lead to the development of new business opportunities in India.

Scenario post appreciation of the Rupee: Once the petrol and diesel prices are de-regulated, fuel will become cheaper and costs of producers will reduce. More exports will bring in more foreign capital and will boost the Rupee further, leading to lower costs and higher margins with more export competitiveness. This will lead to a virtuous cycle that can only lead to a stronger Rupee and more competitiveness of businesses.

The de-regulation of oil prices will also mean that the Government has free capital for more projects leading to more infrastructure development in the country. This will lead to higher employment and more growth. New projects such as national biometrics based database of citizens, biometrics based identification of criminals, high speed railways to connect important business hubs, etc. could now be implemented with the freed up capital from the Government's budget.

The businesses that were operating in the weak Rupee economy will see their costs go down and margins go up. At the same income level, disposable income will now be higher due to the stronger Rupee and lower inflation. Thus the export competitiveness will not be lost due to a strong Rupee and all businesses will be allowed to flourish in such an environment.

\section{References:}

[1]. Rupee's journey since Independence: Down by 65 times against dollar: The Economic Times: http://articles.economictimes.indiatimes.com/2013-08-24/news/41444029_1_indian-rupee-american-currency-continued-dollardemand

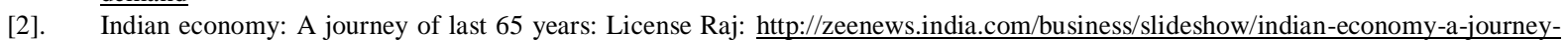
of-last-66-years $68 . \mathrm{html} / 10$

[3]. RBI to buy 20 tonnes of IMF gold: LIVEMINT http://www.livemint.com/Home-Page/BtrypkIoTHQ1g0rYq5JNgP/RBI-to-buy200-tonnes-of-IMF-gold.html

[4]. Rupee is undervalued by 40\%. Fair value would be Rs.40/Dollar: The Economic Times: http://articles.economictimes.indiatimes.com/2012-03-10/news/31143096_1_convertibility-rupee-finance-minister

[5]. India Balance of Trade: TRADINGECONOMICS.COM: http://www.tradingeconomics.com/india/balance-of-trade

[6]. Steel firms bet exports on weak Rupee, domestic slump: The Economic Times http://economictimes.indiatimes.com/markets/commodities/steel-firms-bet-on-exports-on-weak-rupee-domesticslump/articleshow/25264433.cms

[7]. India's power sector reeling under fuel resource crunch: Asian Power http://asian-power.com/powerutility/commentary/india\%E2\%80\%99s-power-sector-reeling-under-fuel-resource-crunch http://www.infodriveindia.com/indiaimport-data/crude-oil-import-data.aspx

[8]. Oil ministry to seek cabinet nod on diesel de-regulation: The Economic Times: http://timesofindia.indiatimes.com/business/indiabusiness/Oil-ministry-to-seek-Cabinet-nod-on-diesel-deregulation/articleshow/40938751.cms

[9]. Diesel prices de-regulated: The Indian Express: http://indianexpress.com/article/business/business-others/diesel-deregulated-pricescut-by-rs-3-37-a-litre/

[10]. Budget 2014, Union Budget: The Financial Express: http://indianexpress.com/article/business/business-others/budget-2014-unionbudget-narendra-modi-gst/ 